\title{
The College Library and the Drop-Out
}

This study shows a statistically significant correlation between library use and persistence among college freshmen at California State Polytechnic College, Pomona. It confirms an earlier study showing correlation between library use and grades. However, no GPA advantage accrued to science and engineering students. Data suggest correlation between on-campus residence and persistence, but ChiSquare test fails to validate the data. Forty-three per cent of non-users of the library dropped out in one year; only 26 per cent of library users dropped out.

D brary have anything to do with the likelihood of his persisting to graduation? From a study of entering freshmen at California State Polytechnic College, Pomona, it appears that it might. This study shows, for example, that of those freshmen who failed to use the library, 43 per cent did not return the following year. But of those who did borrow at least one book, only 26 per cent dropped out.

Interest in the subject of student attrition in the University of California and in California state colleges goes back at least to the summer of 1965 when it was discussed critically in a state legislative committee. A special study ${ }^{1}$ was made at California State Polytechnic College to learn the extent of the problem and how it might be attacked. The report, prepared by a collegewide committee of faculty and staff, stimulated a great deal of interest, of which this study is one expression.

\footnotetext{
${ }^{1}$ Student Persistence Committee, Report (Pomona: The Committee, California State Polytechnic College, Kellogg-Voorhis Campus, 1966).
}

Mr. Kramer is Chief, Reader Services Division, College Library, California State Polytechnic College, Pomona.
Barkey's study ${ }^{2}$ had already indicated that there is a correlation between grade point average and use of a college library. It seemed likely that the attrition rate might also show some relation to library use.

The study is based on a 50 per cent sample of the entering freshman class of 1963/64. Of the 742 first-time freshmen, most were male ( 71 per cent), and most lived off campus (68.6 per cent); nearly all were unmarried (95.5 per cent). There were 251 students in engineering, 83 in agriculture, 92 in the sciences, and 316 in the arts.

The library loan records were studied for the winter quarter 1964 (by which time all freshmen had been issued their borrowers cards). From the registrar's office, name, sex, major, marital status, residence, return or non-return to school in fall 1964, and grade point average were obtained. The number of occasions when books were borrowed, and total number of books borrowed, were recorded.

There were a number of interesting findings. Students who borrowed no books during the quarter earned an av-

${ }^{2}$ Patrick Barkey, "Patterns of Student Use of a College Library," CRL, XXVI (March 1965), 115-18. 
TABLE 1

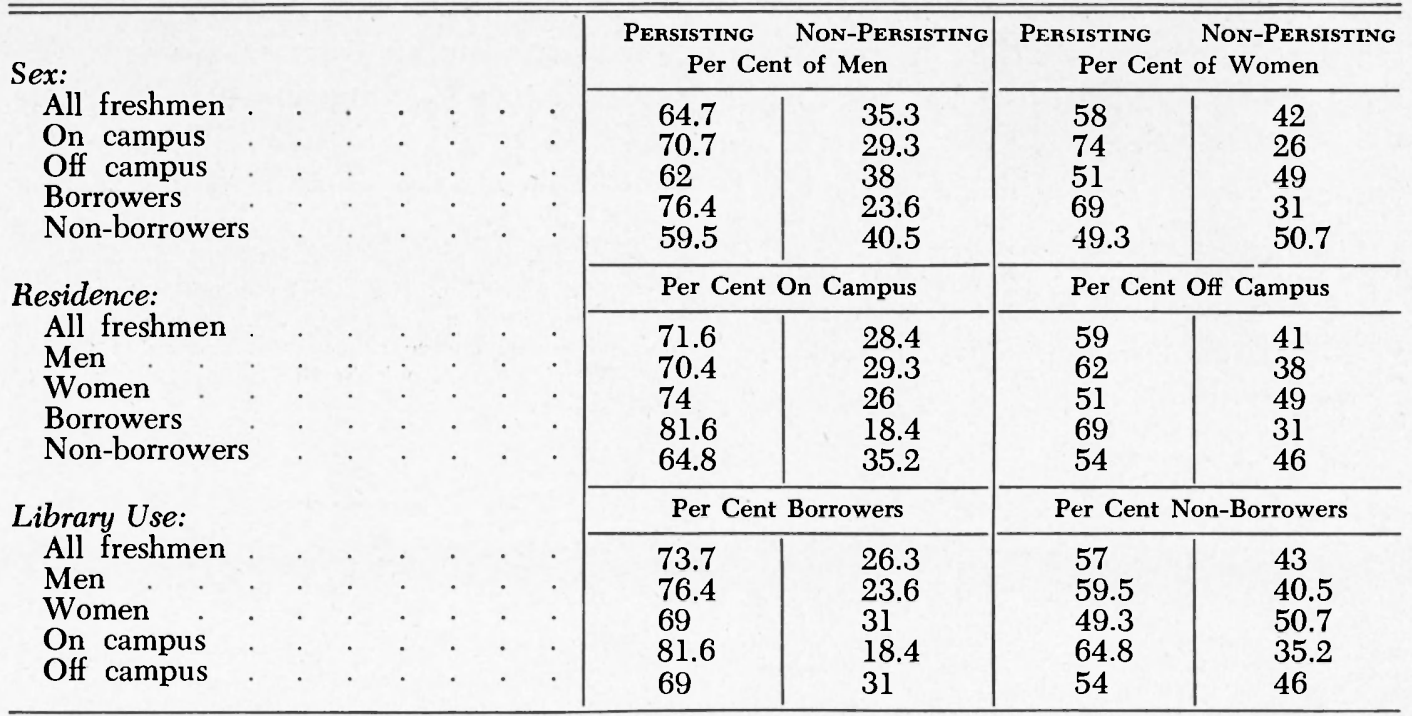

erage GPA of 2.00 (on a 4.0 scale). Library users earned 2.22. This apparent advantage was tested for significance. The data yielded a t-value of 4.26 , more than sufficient, in this population, to validate the significance of the data.

These results, however, varied markedly among majors. No significant GPA advantage accrued to engineering or science majors who used the library. Among arts majors the advantage was 2.37 GPA for library users, against 2.10 for non-users. Among agriculture majors the advantage was 2.13 GPA (users), against 1.70 GPA (non-users).

Figure 1, showing the extent of library use among students of different gradepoint average is of interest. In this chart only the arts and agriculture majors are considered (the curricular areas where library use was found to be significant for grades). Following Barkey ${ }^{3}$ a grade of " $\mathrm{A}$ " was defined as 3.5 to 4.0 , " $\mathrm{B}$ " as 2.5 to 3.0 , "C" as 1.5 to 2.0 , and " $\mathrm{D}$ " as .5 to 1.0. These four grade groups were plotted on the chart to show the percentage of each group making use of the library. The chart shows, for exam-

${ }^{3}$ Ibid. ple, that of those freshmen doing " $A$ " work, 80 per cent used the library.

Tabulation of data for persistence, library use, sex, and residence are given in Table 1.

The data revealed a strong indication that on-campus residence might correlate positively with student persistence. Of the on-campus students, 71.6 per cent persisted. Of the off-campus students, only 59 per cent persisted. However, a Chi Square test yielded a figure

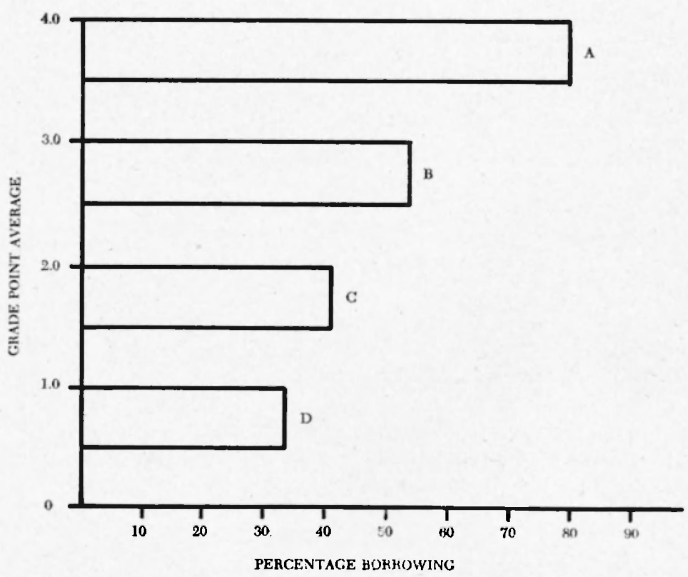

Fig. 1-Library use and grades (percentage of each group borrowing at least one book during the quarter) 
too high to insure the significance of these data.

Only 63 per cent of the class returned the following fall. But of those students who used the library, 73.7 per cent returned. By contrast, the fate of those freshmen who never used the library was that only 57 per cent returned. ${ }^{4}$

This study seems to show a strong and statistically significant correlation between library use and student per- sistence. The fact that 65 per cent of the freshman class borrowed no library books during the quarter studied suggests that counseling and orientation in this area might be productive of better academic success and persistence.

4 These results proved to be significant. A Chi Square test gave a value of 4.22. In a Chi Square table, with one degree of freedom, this value yielded 4 per cent, or well within the 5 per cent level of acceptability.

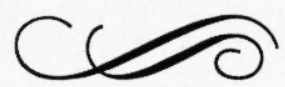

